\title{
Evaluation of the Prognostic Value of Heart Rate Variability in Elderly Patients with Multivessel Coronary Artery Disease against the Background of Invasive and Non-Invasive Treatment
}

\author{
Saodat Ya. Abdullaeva*; Aleksey G. Nikishin, PhD, ScD; \\ Gusal U. Mullabaeva, PhD, ScD; Feruza M. Bekmetova, PhD, ScD \\ Republican Specialized Scientific and Practical Medical Centre of Cardiology \\ Tashkent, Uzbekistan
}

\begin{abstract}
The purpose of this study was to evaluate the prognostic value of heart rate variability (HRV) in elderly patients with multivessel coronary artery disease on the background of invasive and non-invasive treatment.

Methods and Results: This study included 254 patients over age 65 with lesions of the left trunk of the left coronary artery in combination with lesions of 2 or more coronary arteries. To assess HRV, all patients underwent 24-hour Holter ECG monitoring at baseline and one year later. Depending on the treatment strategy, patients were divided into 3 groups. Group 1 consisted of 99 patients who, in addition to the standard treatment, underwent percutaneous coronary intervention (PSI) (from 1 to 4 stents); Group 2 included 86 patients who, in addition to the standard treatment, underwent coronary artery bypass grafting (CABG) (from 2 to 4 shunts); Group 3 included 69 patients who received only optimal drug therapy (ODT). The results have shown that a decrease in HRV is an independent predictor of complications associated with an increase in coronary insufficiency in CAD patients. Such indicators of HRV as SDNN, SDNNi, TP, VLF, and LF have a significant positive predictive value in patients undergoing ODF and/or undergoing PCI. For patients undergoing CABG, at least in the first year after surgery, HRV cannot be considered as an independent prognostic marker. For elderly patients with multivessel coronary artery disease, 24-hour Holter ECG monitoring with subsequent analysis of HRV is recommended to assess the recovery process and pharmacotherapy. (International Journal of Biomedicine. 2021;11(3):260-264.)
\end{abstract}

Key Words: coronary artery disease $\bullet$ heart rate variability $\bullet$ PSI $\bullet$ CABG $\bullet$ drug therapy

For citation: Abdullaeva SYa, Nikishin AG, Mullabaeva GU, Bekmetova FM. Evaluation of the Prognostic Value of Heart Rate Variability in Elderly Patients with Multivessel Coronary Artery Disease against the Background of Invasive and Non-Invasive Treatment International Journal of Biomedicine. 2021;11(3):260-264. doi:10.21103/Article11(3)_OA1

\section{Abbreviations}

ANS. autonomic nervous system; CABG, coronary artery bypass grafting; CAD, coronary artery disease; HR, heart rate; HRV, heart rate variability; HF, heart failure; LVEF, left ventricular ejection fraction; LCA, left coronary artery; ODT, optimal drug therapy; PCI, percutaneous coronary intervention; SD, sudden death.

\section{Introduction}

Coronary artery disease (CAD) remains the most common human disease, and the mortality it causes is higher than all other causes of death. ${ }^{(1)}$ Patients with CAD are a rather heterogeneous group; more than half of them have a multivessel lesion, that is, they represent a complex and severe category of patients. Along with the development of the therapeutic direction of treatment, there is a continuous development of surgical methods for the treatment of CAD. The modern direction of surgical interventions involves both minimally invasive percutaneous coronary intervention (PCI) and open 
heart surgery (coronary artery bypass grafting $[\mathrm{CABG}]$ ). In the light of the constant improvement and development of new directions in CAD treatment, it is relevant to identify various prognostic markers that make it possible to assess the course of the disease, especially since some of the most commonly used indicators, for example, the ejection fraction, in some cases may be insufficiently informative and may not correlate with the severity of the clinical condition, especially with the progression of coronary atherosclerosis. ${ }^{(2)}$

Undoubtedly, dysfunction of the central and autonomic nervous systems, along with heredity and endocrine-metabolic imbalance, is a significant factor affecting the development of CAD. The sympathetic/parasympathetic imbalance leads to an increase in the inflammatory status in the cardiovascular system and biotransformation of atherosclerotic plaques with the development of coronary complications. ${ }^{(3)}$

It should be remembered that the parasympathetic system directly affects the electrophysiological properties of the myocardium, and can also inhibit adrenergic activity. ${ }^{(4)}$ One of the effective and available methods for studying the state of the autonomic nervous system (ANS) is the analysis of heart rate variability (HRV). This method allows us to assess the state of both sympathetic and parasympathetic divisions of the ANS. At the same time, low HRV correlates to a greater extent with the risk of sudden death (SD) than some generally accepted indicators of the clinical severity of the patient's condition: LVEF, ventricular arrhythmias, and degree of exercise tolerance. ${ }^{(3,5,6)}$ With aging, the autonomic effect on the cardiovascular system weakens, and the autonomic regulation of the heart gradually disintegrates. This fact correlates with the results of experimental studies, which have shown a weakening of functional connections between parts of the central nervous system in aged animals. ${ }^{(4,7)}$ The data obtained in a number of studies ${ }^{(7,8)}$ also indicate a weakening of the effect of the ANS on the cardiovascular system with age. ${ }^{(9-11)}$

The purpose of this study was to evaluate the prognostic value of HRV in elderly patients with multivessel coronary artery disease on the background of invasive and non-invasive treatment.

\section{Materials and Methods}

This study included 254 patients over age 65 with lesions of the left trunk of the LCA in combination with lesions of 2 or more coronary arteries. All patients received the standard basic therapy (ODT): antiplatelet therapy (acetylsalicylic acid, clopidogrel), $\beta$-blockers (bisoprolol), ACE inhibitors, statins (rosuvastatin).

Depending on the treatment strategy, patients were divided into 3 groups. Group 1 consisted of 99 patients who, in addition to the standard treatment, underwent PSI (from 1 to 4 stents); Group 2 included 86 patients who, in addition to the standard treatment, underwent $\mathrm{CABG}$ (from 2 to 4 shunts); Group 3 included 69 patients who received only ODT.

Based on the results of one-year follow-up, each group was divided into 2 subgroups: (A) those who reached at least one endpoint and (B) those who did not reach the endpoints.
The following endpoints were studied: lethal outcome, myocardial infarction (non-fatal), progression of coronary insufficiency, development and progression of heart failure $(\mathrm{HF})$, repeated hospitalizations associated with an increase in coronary insufficiency, the need for surgery.

To assess HRV, all patients underwent 24-hour Holter ECG monitoring at baseline and one year later. Key indicators:

$\mathrm{mRR}$ (ms), the average duration of all RR intervals

SDNN (ms), the standard deviation of NN intervals

SDNN index (SDNNi) (ms), the mean of the standard

deviations of all the NN intervals for each 5 min segment of a 24h HRV recording

RMSSD (ms), the square root of the mean squared

difference between adjacent R-R intervals

pNN50, the percentage of successive RR intervals that

differ by more than $50 \mathrm{~ms}$

HF power $\left(\mathrm{ms}^{2}\right)$, the absolute power of the highfrequency band $(0.15-0.4 \mathrm{~Hz})$; LF power $\left(\mathrm{ms}^{2}\right)$, the absolute power of the low-frequency band $(0.04-0.15 \mathrm{~Hz})$

VLF power $\left(\mathrm{ms}^{2}\right)$, the absolute power of the very-lowfrequency band $(0.0033-0.04 \mathrm{~Hz})$

ULF power $\left(\mathrm{ms}^{2}\right)$, the absolute power of the ultra-lowfrequency band $(\leq 0.003 \mathrm{~Hz})$

$\mathrm{TP}$, total power $\left(\mathrm{ms}^{2}\right)$

$\mathrm{LF} / \mathrm{HF}$, the ratio of LF-to-HF power

The results were evaluated using the CardioSens $+v .3 .0$ (KhAI Medica, Ukraine).

Statistical analysis was performed using the statistical software «Statistica». (v6.0, StatSoft, USA). For all types of analysis, the value of $P \leq 0.05$ was considered statistically significant.

\section{Results}

In Group 1 (PCI group), there were no differences in HRV between subgroups at baseline. At the same time, in both subgroups, baseline SDNN $<50 \mathrm{~ms}$ were noted. A number of studies have shown that a decrease in SDNN less than $50 \mathrm{~ms}$ has a predictive value for detecting ventricular arrhythmias and SD risk, ${ }^{(6,12)}$ as well as the LF/HF ratio $>1.5$, which indicates a shift in the autonomic balance towards an increase in sympathetic tone. ${ }^{(13)}$

In the dynamics, there were significant differences in the time-domain HRV indicators between subgroups. In particular, we found a significant increase in night-time SDNN in Subgroup B, compared to Subgroup A $(68.3 \pm 10.8$ $\mathrm{ms}$ vs. $43.2 \pm 8.8 \mathrm{~ms}, P=0.000$ ). Frequency-domain $\mathrm{HRV}$ indicators were also significantly better in Subgroup B than in Subgroup A (LF power: $995 \pm 274.5 \mathrm{~ms}^{2}$ vs. $359.8 \pm 151.4 \mathrm{~ms}^{2}$, $P=0.000$ ), which indicates an increase in the sympathetic tone of the ANS. In general, in Subgroup A, the HRV indicators did not change during one year, compared to Subgroup B, with a positive dynamic of both time-domain and frequencydomain HRV indicators (Table 1). In Subgroup B, we found a decrease in the night-time HR from $76.2 \pm 6.1 \mathrm{bpm}$ to $60.3 \pm 3.6$ bpm $(P=0.01)$, an increase in $\mathrm{mRR}$ from $765.5 \pm 8.5 \mathrm{~ms}$ to $1005.5 \pm 70 \mathrm{~ms}(P=0.01)$. 
Table 1.

\section{HRV indices in PCI group}

\begin{tabular}{|c|c|c|c|c|c|c|c|}
\hline \multirow{2}{*}{ Indicator } & \multicolumn{3}{|c|}{$\underset{(\mathrm{n}=57)}{\text { Subgroup A }}$} & \multicolumn{3}{|c|}{$\underset{(n=42)}{\text { Subgroup } B}$} & \multirow[t]{2}{*}{$P_{\mathrm{A}-\mathrm{B}}$} \\
\hline & baseline & $\begin{array}{c}\text { one-year } \\
\text { follow-up }\end{array}$ & $P$ & baseline & $\begin{array}{c}\text { one-year } \\
\text { follow-up }\end{array}$ & $P$ & \\
\hline $\begin{array}{l}\mathrm{mRR}, \\
\mathrm{ms}\end{array}$ & $\begin{array}{c}868 \\
\pm 146\end{array}$ & $\begin{array}{l}916.5 \\
\pm 64.2\end{array}$ & 0.8 & $\begin{array}{l}765.5 \\
\pm 8.5\end{array}$ & $\begin{array}{l}1005.5 \\
\pm 70\end{array}$ & 0.01 & 0.000 \\
\hline $\begin{array}{l}\text { SDNN, } \\
\mathrm{ms}\end{array}$ & $\begin{array}{l}36.5 \\
\pm 12.5\end{array}$ & $\begin{array}{l}43.2 \\
\pm 8.8\end{array}$ & 0.69 & $\begin{array}{l}29.5 \\
\pm 3.5\end{array}$ & $\begin{array}{c}68.3 \\
\pm 10.8\end{array}$ & 0.01 & 0.000 \\
\hline $\begin{array}{l}\text { SDNNi, } \\
\mathrm{ms}\end{array}$ & $\begin{array}{c}36.9 \\
\pm 12.4\end{array}$ & $\begin{array}{c}39.1 \\
\pm 11.5\end{array}$ & 0.89 & $\begin{array}{l}29.2 \\
\pm 3.3\end{array}$ & $\begin{array}{l}63.9 \\
\pm 9.4\end{array}$ & 0.01 & 0.000 \\
\hline $\mathrm{TP}, \mathrm{ms}^{2}$ & $\begin{array}{l}1470.5 \\
\pm 886.5\end{array}$ & $\begin{array}{l}1900.7 \\
\pm 717.2\end{array}$ & 0.71 & $\begin{array}{c}843 \\
\pm 188\end{array}$ & $\begin{array}{c}3988.5 \\
\pm 1129.8\end{array}$ & 0.02 & 0.000 \\
\hline VLF, $\mathrm{ms}^{2}$ & $\begin{array}{c}617.5 \\
\pm 352.5\end{array}$ & $\begin{array}{l}927.5 \\
\pm 282.3\end{array}$ & 0.54 & $\begin{array}{l}396 \\
\pm 69\end{array}$ & $\begin{array}{l}1280.8 \\
\pm 364.8\end{array}$ & 0.02 & 0.000 \\
\hline $\mathrm{LF}, \mathrm{ms}^{2}$ & $\begin{array}{c}430 \\
\pm 329\end{array}$ & $\begin{array}{c}359.8 \\
\pm 151.4\end{array}$ & 0.87 & $\begin{array}{l}230 \\
\pm 90\end{array}$ & $\begin{array}{c}995 \\
\pm 274.5\end{array}$ & 0.02 & 0.000 \\
\hline $\mathrm{HF}, \mathrm{ms}^{2}$ & $\begin{array}{c}210 \\
\pm 162\end{array}$ & $\begin{array}{c}44 \\
\pm 18.6\end{array}$ & 0.53 & $\begin{array}{c}60.5 \\
\pm 37.5\end{array}$ & $\begin{aligned} & 40 \\
\pm & 13.6\end{aligned}$ & 0.22 & 0.241 \\
\hline LF/HF & $\begin{array}{c}2.2 \\
\pm 0.2\end{array}$ & $\begin{array}{c}4.6 \\
\pm 4.8\end{array}$ & 0.39 & $\begin{array}{c}4.7 \\
\pm 1.4\end{array}$ & $\begin{array}{l}1.9 \\
\pm 1.04\end{array}$ & 0.25 & 0.000 \\
\hline
\end{tabular}

$P_{A-B}$ - between subgroups one year after PCI

Table 2.

\section{HRV indicators in the CABG group}

\begin{tabular}{|c|c|c|c|c|c|c|c|}
\hline \multirow{2}{*}{ Indicator } & \multicolumn{3}{|c|}{$\begin{array}{c}\text { Subgroup A } \\
(\mathrm{n}=52)\end{array}$} & \multicolumn{3}{|c|}{$\underset{(n=34)}{\text { Subgroup B }}$} & \multirow[t]{2}{*}{$P_{\mathrm{A}-\mathrm{B}}$} \\
\hline & baseline & $\begin{array}{c}\text { one-year } \\
\text { follow-up }\end{array}$ & $P$ & baseline & $\begin{array}{c}\text { one-year } \\
\text { follow-up }\end{array}$ & $P$ & \\
\hline $\begin{array}{l}\mathrm{mRR}, \\
\mathrm{ms}\end{array}$ & $\begin{array}{l}878.5 \\
\pm 94.7\end{array}$ & $\begin{array}{l}929.4 \\
\pm 91.3\end{array}$ & 0.78 & $\begin{array}{c}979 \\
\pm 121\end{array}$ & $\begin{array}{l}935.4 \\
\pm 82.7\end{array}$ & 0.78 & 0.758 \\
\hline $\begin{array}{l}\text { SDNN, } \\
\mathrm{ms}\end{array}$ & $\begin{array}{l}34.6 \\
\pm 7.5\end{array}$ & $\begin{array}{c}44.3 \\
\pm 10.9\end{array}$ & 0.59 & $\begin{array}{c}59.5 \\
\pm 24.5\end{array}$ & $\begin{array}{c}43 \\
\pm 4.3\end{array}$ & 0.62 & 0.510 \\
\hline $\begin{array}{l}\text { SDNNi, } \\
\mathrm{ms}\end{array}$ & $\begin{array}{l}38.5 \\
\pm 8.3\end{array}$ & $\begin{array}{c}44.2 \\
\pm 10.9\end{array}$ & 0.82 & $\begin{array}{c}59.8 \\
\pm 24.4\end{array}$ & $\begin{array}{l}44.6 \\
\pm 5.7\end{array}$ & 0.65 & 0.844 \\
\hline $\mathrm{TP}, \mathrm{ms}^{2}$ & $\begin{array}{c}1549 \\
\pm 783.5\end{array}$ & $\begin{array}{l}2017.6 \\
\pm 977.8\end{array}$ & 0.72 & $\begin{array}{c}4075 \\
\pm 2833\end{array}$ & $\begin{array}{l}1992.5 \\
\pm 507.6\end{array}$ & 0.6 & 0.891 \\
\hline VLF, $\mathrm{ms}^{2}$ & $\begin{array}{c}717.4 \\
\pm 264.8\end{array}$ & $\begin{array}{l}1014.4 \\
\pm 496.5\end{array}$ & 0.46 & $\begin{array}{l}1615 \\
\pm 940\end{array}$ & $\begin{array}{c}984.8 \\
\pm 274.9\end{array}$ & 0.62 & 0.752 \\
\hline $\mathrm{LF}, \mathrm{ms}^{2}$ & $\begin{array}{c}426.3 \\
\pm 128.8\end{array}$ & $\begin{array}{c}336.3 \\
\pm 130.9\end{array}$ & 0.82 & $\begin{array}{l}1070.5 \\
\pm 896.5\end{array}$ & $\begin{array}{c}389.1 \\
\pm 187.4\end{array}$ & 0.59 & 0.128 \\
\hline $\mathrm{HF}, \mathrm{ms}^{2}$ & $\begin{array}{l}184.5 \\
\pm 68.2\end{array}$ & $\begin{array}{l}272.7 \\
\pm 177\end{array}$ & 0.62 & $\begin{array}{c}621 \\
\pm 578\end{array}$ & $\begin{array}{c}195.8 \\
\pm 132.1\end{array}$ & 0.6 & 0.033 \\
\hline $\mathrm{LF} / \mathrm{HF}$ & $\begin{array}{c}2.1 \\
\pm 0.6\end{array}$ & $\begin{array}{c}1.9 \\
\pm 0.8\end{array}$ & 0.29 & $\begin{array}{c}2.9 \\
\pm 1.3\end{array}$ & $\begin{array}{l}2.6 \\
\pm 1\end{array}$ & 0.88 & 0.001 \\
\hline
\end{tabular}

$P_{A-B}$, between subgroups one year after $C A B G$
A significant increase in such indicators as SDNN, including SDNNi (from $29.2 \pm 3.3 \mathrm{~ms}$ to $63.9 \pm 9.4 \mathrm{~ms}, P=0.01$ ), TP (from $843 \pm 188 \mathrm{~ms}^{2}$ to $3988.5 \pm 1129.8 \mathrm{~ms}^{2}, P=0.02$ ), and VLF power from $396 \pm 69 \mathrm{~ms}^{2}$ to $1280.8 \pm 364.8 \mathrm{~ms}^{2}, P=0.02$ ) indicates a reliable predictive value of the HRV changes (Table 1).

In Group 2 (CABG group), there were no differences between subgroups, both at baseline and one year later (Table 2). In generally, the dynamics of HRV indices was not so pronounced, which, most likely, is associated with surgical intervention that disturbs the neurohumoral relations and a relatively short follow-up period. Previously, it was shown that one year after CABG, HRV parameters remain sharply reduced, while in patients with CABG performed 3 years ago, the values of the main HRV parameters are close to patients with normal HRV parameters, i.e. there is a certain restoration not only of the coronary circulation but also of the neurohumoral relations. ${ }^{(14)}$

In Group 3 (ODT group), there were no baseline differences in HRV in subgroups. It should be noted, however, there was a general decrease in HRV. In dynamics, the best HRV indicators were observed in Subgroup B (Table 3).

Table 3.

HRV indices in ODT group

\begin{tabular}{|c|c|c|c|c|c|c|c|}
\hline \multirow{2}{*}{ Indicator } & \multicolumn{3}{|c|}{$\begin{array}{c}\text { Subgroup A } \\
(\mathrm{n}=46)\end{array}$} & \multicolumn{3}{|c|}{$\underset{(n=23)}{\text { Subgroup A }}$} & \multirow[t]{2}{*}{$P_{\mathrm{A}-\mathrm{B}}$} \\
\hline & baseline & $\begin{array}{l}\text { one-year } \\
\text { follow-up }\end{array}$ & $P$ & baseline & $\begin{array}{l}\text { one-year } \\
\text { follow-up }\end{array}$ & $P$ & \\
\hline $\begin{array}{l}\mathrm{mRR} \\
\mathrm{ms}\end{array}$ & $\begin{array}{l}1017 \\
\pm 66.1\end{array}$ & $\begin{array}{c}909.8 \\
\pm 104.9\end{array}$ & 0.03 & $\begin{array}{l}812.4 \\
\pm 72.3\end{array}$ & $\begin{array}{c}920.4 \\
\pm 164.3\end{array}$ & 0.02 & 0.746 \\
\hline $\begin{array}{l}\text { SDNN, } \\
\mathrm{ms}\end{array}$ & $\begin{array}{l}49.1 \\
\pm 0.9\end{array}$ & $\begin{array}{l}38.1 \\
\pm 9.1\end{array}$ & 0.59 & $\begin{array}{l}28.7 \\
\pm 4.9\end{array}$ & $\begin{array}{l}54.6 \\
\pm 8.2\end{array}$ & 0.02 & 0.000 \\
\hline $\begin{array}{l}\text { SDNNi, } \\
\text { ms }\end{array}$ & $\begin{array}{l}47.1 \\
\pm 1.6\end{array}$ & $\begin{array}{c}38.2 \\
\pm 9.04\end{array}$ & 0.04 & $\begin{array}{c}778.5 \\
\pm 224.8\end{array}$ & $\begin{array}{l}44.2 \\
\pm 7.9\end{array}$ & 0.02 & 0.009 \\
\hline $\mathrm{TP}, \mathrm{ms}^{2}$ & $\begin{array}{l}2191 \\
\pm 152\end{array}$ & $\begin{array}{l}1511.9 \\
\pm 717.5\end{array}$ & 0.06 & $\begin{array}{l}1142.3 \\
\pm 218.5\end{array}$ & $\begin{array}{l}2003.4 \\
\pm 704.9\end{array}$ & 0.02 & 0.009 \\
\hline VLF, $\mathrm{ms}^{2}$ & $\begin{array}{l}1188.5 \\
\pm 87.5\end{array}$ & $\begin{array}{l}763.8 \\
\pm 368\end{array}$ & 0.04 & $\begin{array}{c}569.3 \\
\pm 221.5\end{array}$ & $\begin{array}{l}1118.4 \\
\pm 608.2\end{array}$ & 0.04 & 0.004 \\
\hline $\mathrm{LF}, \mathrm{ms}^{2}$ & $\begin{array}{l}284 \\
\pm 82\end{array}$ & $\begin{array}{c}245.6 \\
\pm 135.5\end{array}$ & 0.74 & $\begin{array}{l}264.1 \\
\pm 88.5\end{array}$ & $\begin{array}{l}853.8 \\
\pm 99.4\end{array}$ & 0.03 & 0.000 \\
\hline $\mathrm{HF}, \mathrm{ms}^{2}$ & $\begin{array}{l}120 \\
\pm 63\end{array}$ & $\begin{array}{c}120.5 \\
\pm 77\end{array}$ & 0.99 & $\begin{array}{c}995.8 \\
\pm 673.6\end{array}$ & $\begin{array}{l}1227.2 \\
\pm 674.6\end{array}$ & 0.24 & 0.000 \\
\hline $\mathrm{LF} / \mathrm{HF}$ & $\begin{array}{c}2.8 \\
\pm 0.8\end{array}$ & $\begin{array}{c}2.3 \\
\pm 0.7\end{array}$ & 0.66 & $\begin{array}{c}2.2 \\
\pm 1.7\end{array}$ & $\begin{array}{c}2.9 \\
\pm 1.4\end{array}$ & 0.46 & 0.02 \\
\hline
\end{tabular}

$P_{A-B}$ - between subgroups one year after ODT

In particular, a greater increase in SDNN can be noted in Subgroup B (54.6 $\pm 8.2 \mathrm{~ms})$ than in Subgroup A (38.1 \pm 9.1 $\mathrm{ms})(P=0.000)$. The VLF power was $1118.4 \pm 608.2 \mathrm{~ms}^{2}$ in Subgroup B and $763.8 \pm 368 \mathrm{~ms}^{2}$ in Subgroup A $(P=0.004)$. In Subgroup A, we found no positive dynamics in HRV; 
a decrease in $\mathrm{mRR}$ from $1017 \pm 66.1 \mathrm{~ms}$ to $909.8 \pm 104.9 \mathrm{~ms}$ $(P=0.03)$, SDNNi from $47.1 \pm 1.6 \mathrm{~ms}$ to $38.2 \pm 9.04 \mathrm{~ms}(P=0.04)$, as well as VLF power from $1188.5 \pm 87.5 \mathrm{~ms}^{2}$ to $763.8 \pm 368$ $\mathrm{ms}^{2}(P=0.04)$. On the contrary, in Subgroup B, a significant positive dynamic of both time-domain and frequency-domain HRV indicators was recorded. SDNN and $\mathrm{mRR}$ significantly increased, and not only relative to the initial data, but also more than $50 \mathrm{~ms}$, which significantly reduces the SD risk. ${ }^{(15)}$ The frequency-domain HRV parameters also improved: TP from $1142.3 \pm 218.5 \mathrm{~ms}^{2}$ to $2003.4 \pm 704.9 \mathrm{~ms}^{2}(P=0.02)$, VLF power from $569.3 \pm 221.5 \mathrm{~ms}^{2}$ to $1118.4 \pm 608.2 \mathrm{~ms}^{2}(P=0.04)$, LF power from $264.1 \pm 88.5 \mathrm{~ms}^{2}$ to $853.8 \pm 99.4 \mathrm{~ms}^{2}(P=0.03)$

\section{Discussion}

HRV assessment is well known as a method for predicting unfavorable outcomes in various cardiovascular diseases. The first major study to demonstrate the predictive ability of HRV in relation to overall mortality was the study by Kleiger et al., ${ }^{(3)}$ which started in 1987 and overturned the accepted ideas about the features of the course of the early period after acute myocardial infarction. In that study, the Holter tapes of 808 patients who survived acute myocardial infarction were analyzed. HRV was defined as SDNN in a 24-hour continuous electrocardiogram recording made $11 \pm 3$ days after acute myocardial infarction. The mean follow-up time was 31 months. The relative risk of mortality was 5.3 times higher in the group with SDNN less than $50 \mathrm{~ms}$ than in the group with SDNN of more than $100 \mathrm{~ms}$. A hypothesis to explain this finding is that decreased HRV correlates with increased sympathetic or decreased vagal tone, which may predispose one to ventricular fibrillation.

According to our study, the dynamics of HRV indices has a significant prognostic value in elderly patients with multivessel coronary artery disease, especially in patients who underwent PCI with stenting of one or more arteries on the background of ODT, and in patients receiving only ODT. In patients who had CABG, the dynamics of HRV indices was not so pronounced, which, most likely, is associated with surgical intervention that disturbs the neurohumoral relations and a relatively short follow-up period. ${ }^{(14)}$ Initially, there were no differences in subgroups, while it should be noted that SDNN values $<50 \mathrm{~ms}$ were recorded in all 3 groups, which is a marker of a poor prognosis (in particular, ventricular arrhythmias and the SD risk). ${ }^{(16-18)}$

According to the results of the annual observation, significant differences in the time-domain indicators of HRV between subgroups are recorded. In particular, a significant increase in SDNN can be noted in Subgroup B of patients who underwent PCI. Frequency-domain HRV indices were also significantly better in the subgroup of patients who did not reach any endpoint than in the subgroup of patients who reached at least one endpoint, which indicates an increase in the sympathetic tone of the ANS.

In the ODT group, a similar dynamic was observed: a greater increase in SDNN in Subgroup B than in Subgroup A. Among the frequency-domain HRV indicators, the VLF was a noteworthy index.
Thus, the study of time-domain and frequency-domain HRV indicators is a very promising tool in the study of the ANS in elderly patients with multivessel coronary artery disease. It should be noted that the method has advantages, such as non-invasiveness, safety, and the possibility of long-term observation. The relationship between HRV and the structural and functional state of the heart in CAD, in particular, after $\mathrm{CABG}$, has not been sufficiently studied. In this regard, further research is needed to study HRV in elderly patients.

\section{Conclusions}

1. A decrease in HRV is an independent predictor of complications associated with an increase in coronary insufficiency in CAD patients.

2. Such indicators of HRV as SDNN, SDNNi, TP, VLF, and LF have a significant positive predictive value in patients undergoing ODT and/or undergoing PCI.

3. For patients undergoing $\mathrm{CABG}$, at least in the first year after surgery, HRV cannot be considered as an independent prognostic marker.

4. For elderly patients with multivessel coronary artery disease, 24-hour Holter ECG monitoring with subsequent analysis of HRV is recommended to assess the recovery process and pharmacotherapy.

\section{Competing Interests} interests.

The authors declare that they have no competing

\section{References}

1. Osodchiy OE, Pokrovsky VM. [Peptide modulation of changes in the duration of the cardiac cycle in vagal sinus arrhythmia]. Kardiologiia. 2000;(2):57-64. [Article in Russian].

2. Bekmetova FM, Fozilov KG, Doniyorov S.N. et al. Relationship between the Deformation Properties of the Left Ventricle and the Severity of Coronary Atherosclerosis in Patients with Coronary Artery Disease. International Journal of Biomedicine. 2021;11(2):131-136. doi: 10.21103/ Article11(2) OA1

3. Kleiger RE, Miller JP, Bigger JT Jr, Moss AJ. Decreased heart rate variability and its association with increased mortality after acute myocardial infarction. Am J Cardiol. 1987 Feb 1;59(4):256-62. doi: 10.1016/00029149(87)90795-8.

4. Alieva MA, Bulaeva NI, Gromova OI, Golukhova EZ. [Heart rate variability in assessment of the clinical state and prognosis in congestive heart failure]. Creative Cardiology. 2015;9(3):42-55. [Article in Russian].

*Corresponding author: Saodat Ya. Abdullaeva. Republican Specialized Scientific and Practical Medical Centre of Cardiology. Tashkent, the Republic of Uzbekistan. E-mail: saodat.abdullaeva@, gmail.com 
5. Bigger JT Jr, Fleiss JL, Steinman RC, Rolnitzky LM, Schneider WJ, Stein PK. RR variability in healthy, middleaged persons compared with patients with chronic coronary heart disease or recent acute myocardial infarction. Circulation. 1995 Apr 1;91(7):1936-43. doi: 10.1161/01.cir.91.7.1936.

6. Heart rate variability: standards of measurement, physiological interpretation and clinical use. Task Force of the European Society of Cardiology and the North American Society of Pacing and Electrophysiology. Circulation. 1996 Mar 1;93(5):1043-65.

7. Frolkins VV, Verhratsky NS, Shevchuk VG. [Nervous regulation of heart function during aging]. Physiol Journal of the USSR. 1977;63:1134-1143. [Article in Russian].

8. Korkushko OV, Pisaruk AV, Khristoforova AM, Lutsik MYu. [Relationship between cardiac arrhythmias and autonomic influences on the heart in elderly patients with chronic ischemic heart disease]. Problemy Stareniia I Dolgoletiia. 1998;(2):140-144. [Article in Russian].

9. Geovanini GR, Vasques ER, de Oliveira Alvim R, Mill JG, Andreão RV, Vasques BK, Pereira AC, Krieger JE. Age and Sex Differences in Heart Rate Variability and Vagal Specific Patterns - Baependi Heart Study. Glob Heart. 2020 Oct $21 ; 15(1): 71$. doi: 10.5334/gh.873.

10. Zulfiqar U, Jurivich DA, Gao W, Singer DH. Relation of high heart rate variability to healthy longevity. Am J Cardiol. 2010 Apr 15;105(8):1181-5. doi: 10.1016/j. amjcard.2009.12.022.

11. Abhishekh HA, Nisarga P, Kisan R, Meghana A, Chandran
S, Trichur Raju, Sathyaprabha TN. Influence of age and gender on autonomic regulation of heart. J Clin Monit Comput. 2013 Jun;27(3):259-64. doi: 10.1007/s10877-012-9424-3.

12. Libby P, Ridker PM, Maseri A. Inflammation and atherosclerosis. Circulation. 2002 Mar 5;105(9):1135-43. doi: 10.1161/hc0902.104353.

13. Mikhailov VM. Heart rate variability: Experience of practical application of the method. Ivanovo, 2000. [In Russian].

14. Dubachev A.A. Assessment of heart rate variability in patients undergoing coronary artery bypass grafting. Abstract of PhD Thesis. Kursk, 2012. [In Russian].

15. Sokolov SF, Malkina TA. [Clinical significance of assessing heart rate variability]. Heart. 2002;1(2):72-75. [Article in Russian].

16. Yavelov IS, Deev AD, Travina EE, Gratsiansky NA. [Predictive value of the average frequency of contractions and heart rate variability, assessed in a short time under standard conditions in the early stages of myocardial infarction]. Kardiologiia. 1999;(6):6-13. [Article in Russian].

17. Shaffer F, Ginsberg JP. An Overview of Heart Rate Variability Metrics and Norms. Front Public Health. 2017 Sep 28;5:258. doi: 10.3389/fpubh.2017.00258.

18. Erdogan A, Coch M, Bilgin M, Parahuleva M, Tillmanns H, Waldecker B, Soydan N. Prognostic value of heart rate variability after acute myocardial infarction in the era of immediate reperfusion. Herzschrittmacherther Elektrophysiol. 2008 Dec;19(4):161-8. doi: 10.1007/s00399-008-0024-3. 